Monograph "Universities and Regional Development: the challenge in the era of the globalisation of higher education"

ARTICLE

\title{
New technologies and innovation in higher education and regional development
}

\author{
Tapio Varis
}

Date of presentation: June 2007

Date of acceptation: June 2007

Date of publication: October 2007

\begin{abstract}
According to the Academy of Finland and Tekes, the Finnish Funding Agency for Technology and Innovation, there are two prominent driving forces in today's global operating environment. The first is the trend towards increasing mobility; the second is the growing interdependence of different parts of the world, their increasing interaction and cooperation in the economy, production, social development, communications and human exchange. In today's global and technological world, learning has become increasingly important to all people and all communities. It is widely understood that the most important skills of the future will be communication skills. Today, everyone is able to access vast amounts of data without a mediator. Critical thinking skills are needed as a productive and positive activity. Critical thinkers see the future as open and malleable, not as closed and fixed. As noted in the UNESCO Report on Knowledge Societies (2005), there is a general agreement on the appropriateness of the expression "knowledge societies"; the same cannot be said of the content. However we define the $2 \mathrm{I}^{\text {st }}$ century societies there are some trends that seem to have consequences in all spheres of life. Globalization and digitalization have fundamental consequences in educational and learning life, working life and in governance. The vision is a society which develops and utilizes the opportunities inherent in the information society to improve the quality of life, knowledge, international competitiveness and interaction in an exemplary, versatile and sustainable way. These ideas have been used to develop the Global University System (GUS) within the UNESCO Chair in global e-learning at the University of Tampere. Because of the importance of media and digital literacy and competencies, in 2007 the Government of Finland published a Proposal for an action programme for developing media skills and knowledge as part of the promotion of civil and knowledge society. The reason for setting up this committee was the topicality and importance of media education as part of citizenship skills and the problems encountered in its realization.
\end{abstract}

\section{Keywords}

higher education, Finland, universities and innovation, new technology in higher education, regional innovation 


\title{
Nuevas tecnologías e innovaciones en la educación superior y el desarrollo regional
}

\begin{abstract}
Resumen
Según la Academia de Finlandia y Tekes, la agencia finlandesa de financiación de tecnología e innovación, existen dos fuerzas motrices que destacan dentro del entorno operativo global actual: la primera es la tendencia a una movilidad cada vez mayor y la segunda, la progresiva interdependencia de las diferentes partes del mundo, su paulatina interacción y colaboración en la economía, producción, desarrollo social, comunicaciones e intercambio humano. En el mundo global y tecnológico de hoy día, el aprendizaje ha ido cobrando cada vez más relevancia para todos los pueblos y comunidades. Las aptitudes para la comunicación serán consideradas, sin lugar a dudas, las habilidades más importantes en el futuro. En la actualidad, todo el mundo es capaz de acceder a una gran cantidad de información sin la necesidad de un mediador. Es por ello por lo que se requiere la capacidad de pensamiento critico para que la actividad resulte productiva a la vez que positiva. El pensador crítico percibe el futuro como algo abierto y maleable y no como algo cerrado y fijo. Como apunta el informe de la Unesco «Hacia las sociedades del conocimiento» (2005), hay una aceptación general en cuanto a la adecuación de la expresión sociedades del conocimiento, aunque no se puede decir lo mismo de su contenido. No obstante, algunas de las tendencias que encontramos al describir las sociedades del siglo XXI parecen tener consecuencias en todos los ámbitos de la vida. Por ejemplo, la globalización y la digitalización conllevan efectos importantes en las actividades educativas $y$ de aprendizaje, en la vida laboral asi como en el Gobierno. Lo ideal es una sociedad que progrese y sepa aprovechar aquellas oportunidades intrinsecas a la sociedad de la información para mejorar asi su calidad de vida, los conocimientos, la competitividad internacional y la interacción de una forma ejemplar, versátil y sostenible. Éstas son las ideas que han servido para desarrollar el Sistema Universitario Global (GUS) dentro de la Cátedra Unesco de e-learning global en la Universidad de Tampere. Debido a la importancia de la alfabetización y competencias tanto digitales como de los medios de comunicación, el Gobierno de Finlandia publicó en el año 2007 una propuesta para un programa de acción destinado al desarrollo de las habilidades y conocimientos de los medios como parte promocional de una sociedad civil y del conocimiento. La razón para establecer este comité fue la actualidad y repercusión de la enseñanza de los medios de comunicación dentro de las capacidades para la ciudadanía y los problemas encontrados para su consecución.
\end{abstract}

\section{Palabras clave}

educación superior, Finlandia, universidades e innovación, nuevas tecnologías en la enseñanza superior, innovación regional

\section{Introduction}

At the beginning of 2005 , the Academy of Finland, an expert organisation in basic long-term research funding, joined forces with Tekes, the Finnish Funding Agency for Technology and Innovation, to launch a foresight project under the heading of FinnSight 2015. According to this project, since the r 990 os Finland has advanced to an increasingly innovation-driven stage of development. As the rate of fixed investment declined in the wake of recession, so private and public investment in research, technology and innovation began to climb sharply. Such investment is crucial to economic growth. The challenge for the future is to develop new independent science, technology and innovation policy solutions. Such is the speed of change that we now have to structurally assess our research and innovation systems. Networking, new relations of cooperation and multi- and interdisciplinarity are set to become increasingly important success factors. The impacts and effectiveness of research and innovation systems in society will also assume increasing prominence. In advanced countries, the science and technology policy response to these challenges is to step up foresighting efforts. Foresighting has developed out of the cooperation between surveys of the future (and especially drivers), strategic planning and policy analysis. The target is to identify changes and challenges in the research and innovation environment and to assess how to best respond to these changes.

Finland has worked consistently over a long period of time to build up an advanced research and innovation system whose main strengths include close cooperation and networking at all levels. In international comparisons of competitiveness, Finland has always performed exceptionally well in functions related to competence. Examples include the country's highly qualified workforce, public and private investment in research and innovations, world-class 
researcher intensity and the level of technology development and utilisation.

There are two prominent driving forces in today's global operating environment. The first is the trend towards increasing mobility: the flow of goods, money, capital, people, ideas, cultures and values across national boundaries is continuing to expand. The second is the growing interdependence of different parts of the world, their increasing interaction and cooperation in the economy, production, social development, communications and human exchange. Globalisation today is very much capital driven. Indeed, it has been suggested that national industrial economies are collapsing and giving way to a new international, investordriven monetary system.

In the Finnish analysis, the driving forces of the $2 \mathrm{I}^{\mathrm{st}}$ century are:

\section{- Globalisation}

- Demographic changes

- Science and technology

- Sustainable development

- Changes in knowledge and competence

- Changes in work and people's mental resources

- Changes in the cultural environment

- Governance and safety and security

In today's global and technological world, learning has become increasingly important to all people and all communities; it is the best way to cope and manage in a competitive and ever-changing environment. The development of learning is no longer the exclusive domain of education professionals: a whole host of experts from different fields are needed to organize as well as to support, produce and supervise learning. Key challenges for the global information society are to gain an understanding of virtual and actual knowledge creation processes, to steer and manage those processes and to integrate them with other activities.

The world of work is in constant change. For reasons of cost efficiency, there is a growing tendency to relocate manufacturing to countries where labour costs are lower. The markets for skills and competencies are global. Expertise can be exported anywhere in the world, wherever it is in demand. On the other hand, experts can be recruited from any corner of the world. Increasing numbers of knowledge workers today work in short-term assignments where their individual skills and expertise are needed as part of a broader project. This has promoted mobile work and distributed organizations. Managing distributed work is a major challenge. The communication between employees and their managers may be based only on virtual contacts.
Information technology and information networks have made learning and knowledge independent from the constraints of time and space. Information is created and distributed globally online via social software. Wikis, blogs and RSS services with aggregators are facilitating online learning in networks and various kinds of communities. Many young people in the IT sector now consider this social software and sharing technologies as the most important way of learning. Extra-institutional learning should be integrated with formal education at all levels so that people are not divided into two separate worlds of education. On the other hand, given the growing requirements of efficiency in learning, the world of formal education also needs to adopt new modes of learning.

Whether we are talking about individual, team, community or network learning, this is always a multidisciplinary process. Complex technologies, the ethical dilemmas related to these technologies, increasing multiculturalism and the social problems faced by both adults and young people all combine to put learning under considerable pressure. Apart from natural sciences knowledge and IT and information society competencies, steps are needed to strengthen people's practical skills as well, such as various manual skills as well as all-round general education in children, young people and adults. Culture and the arts can serve in the role of promoting and supporting learning.

Information and communications technologies are profoundly reshaping ways of doing business and other aspects of society. The main challenge is presented by the rapid growth of expertise and competence in emerging economies and by the need to integrate citizens' information society competencies in this process of change.

\section{Global University in the Knowledge Societies}

As noted in the UNESCO Report on Knowledge Societies $(2005)$, there is a general agreement on the appropriateness of the expression "knowledge societies"; the same cannot be said of the content. We have to ask which type of knowledge we are talking about. Are we endorsing the hegemony of the techno-scientific model in defining legitimate and productive knowledge? Also the term "Digital Age" has been questioned as a Western concept, and some speakers prefer a multicultural world instead. Art is needed as a means to learn from another culture. Furthermore, there are grave imbalances and obstacles that mark the access to knowledge both locally and globally. 
However we define the $2 \mathrm{I}^{\text {st }}$ century societies, there are some trends that seem to have consequences in all spheres of life. Globalization and digitalization have fundamental consequences in educational and learning life, working life and in governance. Not only money and technology are moving, but markets and partnerships become global and labour becomes increasingly mobile. The issue of multiculturalism becomes central and people live in media environments of multiple identities. There is also the threat of becoming marginalized and excluded.

We are facing a third major educational invention in technology. The first was the phonetic alphabet, the second printing, and now the third is telematics, which means computers connected to networks. There is a need for a new global strategy for promoting the role of information and communication technology (ICT) in different fields of the working life in the emerging knowledge societies and developing educational and training approaches on how to learn the use of ICT and become digitally literate in the spirit of sustainable development.

Traditional alphabetical competencies include basic operational competencies related to texts, psycho-cognitive competencies related to alphabetic signs, basic reading and writing, basic mathematical and textual comprehension, and socio-communicative competencies. Digital competence includes basic operational competencies related to screens and computers, psycho-cognitive competencies related to computer signs, basic computer competence, interactive media and on-line competence, and global sociocommunicative competence associated to cyberspace.

Digital literacy is a fundamental element of the knowledge society. In Europe, it is now seen as a right for all. Ensuring that everyone has the necessary skills, competences, experiences and attitudes to make effective use of ICT is probably the biggest challenge of all. The illiterates of the $2 \mathrm{I}^{\text {st }}$ century are not those who cannot read and write but those who cannot learn, unlearn, and relearn. Different terms are being used in different countries to refer to media education and media literacy. While the educational approaches are discussed in some countries under the title "media pedagogy" and traditional literacy is extended to include "media literacy", "digital literacy", "technological literacy, "visual literacy”, "cultural literacy" etc a more broader approach has been also developed under the title "media competence." A most recent demand comes from e-media and e-learning, which covers a wide set of applications and processes such as Web-based learning, computer-based learning, virtual classrooms, and digital collaboration.

It is widely understood that the most important skills of the future will be communication skills. Today, everyone is able to access vast amounts of data without a mediator. Critical thinking skills are needed as a productive and positive activity. Critical thinkers see the future as open and malleable, not as closed and fixed. They are aware of the diversity of values, behaviours, social structures and artistic forms in the world. Critical thinking is a process, not an outcome, and it is emotive as well as rational.

According to the UNESCO International Institute for Educational Planning, higher education institutions worldwide face significant challenges related to providing increased access, while containing or reducing costs. Meeting increasing and increasingly varied demand for quality higher education is an important consideration in policy debate and institutional development in many countries. New developments in higher education - from virtual universities and cross-border education to e-learning, blended learning and open educational resources - all speak of the efforts on the part of the traditional higher education community, as well as new providers, to address the challenges they face in increasing provision. (Unesco International Institute for Educational Planning 2005).

Globalisation is consolidated by the extraordinary invasion of higher education by new technologies, especially the Internet. The development of communication and information technologies makes it possible for distance teaching institutions to strengthen their position in the educational landscape. They also pave the way for lifelong education for all and at the same time are spreading the traditional universities, more and more of which use distance teaching methods in their activities, thereby making the distinction between the two types of institutions virtually meaningless. There is an increasing number of university networks of this kind all over the world, and the use of computers in the learning process, access to the Internet by students as a vehicle for self-directed learning, educational broadcasting and video-conferencing are all being stepped up.

In the information society, knowledge forms the foundation for education and culture and constitutes the single most important production factor. Information and communications technology significantly promotes interaction and exchange of information between individuals, business enterprises, and other organizations, as well as the provision of, and access to, services. The extent to which the information society is implemented in schools and libraries, healthcare, the promotion of business and industry and other administrative services, as well as enhancing transparent decision-making, largely depends on the decisions made and the measures taken by local authorities.

The vision is a society which develops and utilizes the opportunities inherent in the information society to 
improve the quality of life, knowledge, international competitiveness and interaction in an exemplary, versatile and sustainable way. These ideas have been used to develop the Global University System (GUS) within the UNESCO Chair in global e-learning at the University of Tampere.

The Global University System (GUS) is a worldwide initiative to create satellite/wireless telecommunications infrastructure and educational programmes for access to educational resources across national and cultural boundaries for global peace. The GUS helps higher educational institutions in remote/rural areas of developing countries to deploy broadband Internet in order for them to close the digital divide and act as the knowledge centre of their community for the eradication of poverty and isolation. The GUS has task forces working in the major regions of the globe with partnerships of higher education and healthcare institutions. Learners in these regions will be able to take their courses, via advanced broadband Internet, from member institutions around the world to receive a GUS degree. These learners and their professors from participating institutions will form a global forum for the exchange of ideas and information and for conducting collaborative research and development. The aim is to achieve "education and healthcare for all," anywhere, anytime and at any pace. (Varis - Utsumi - Klemm 2003).

The mission of the GUS has three specific thrusts, to:

- Identify, test, and facilitate the deployment of broadband Internet and related technologies that are affordable and accessible for underdeveloped areas of the world,

- Coordinate the delivery of content and rich educational experiences leading to a GUS degree,

- Provide a global infrastructure for collaboration among faculty, students, graduates, and policy makers in universities, healthcare institutions, corporations, and governments.

The highest priority of the GUS is to launch a transcultural, global initiative (using modern techniques of communication) to promote the kinds of global education that will advance peace, justice, understanding and human wisdom. GUS has no intention of dictating morality to its participants. It will encourage free and open dialog among those with differing opinions and outlooks. But, in view of the challenges confronting humankind at this critical juncture in its history, it behoves us to demonstrate moral leadership in the various activities we undertake.

In a world now fragmented by hosts of competing special interests, a globe endangered by the tribal rivalries of the nation-states, we affirm our university as a place where teaching and thinking are given free reign to be truly ecological - to address problems and crises that are global in scope. The GUS will place an emphasis on quality in all its programmes and courses of instruction. It will draw its curriculum from known centres of learning around the world and seek to identify new centres of excellence and creative scholarship. The undertakings of the GUS will include the most up-to-date research and methods, the most recent developments and insights in its various fields of study, and will be supported and enhanced by the latest advances in communication technology. To respond to the immediate needs of its students, the GUS will offer culturally relevant educational experiences not readily available in local institutions, perhaps not available through any other means but an electronic university, that is interactive in nature and global in scope.

At the same time, the GUS will remain cognizant of the collective needs of the globe. Recognizing that the welter of newly generated information and technologies can itself constitute a significant problem for humankind as a whole, the GUS will seek to temper the fragmentizing effects of contemporary innovation. The GUS will encourage curricula in which the latest facts and newest techniques are grounded and integrated with the wisdom of our oldest traditions, holistic and ecological approaches found at the core of every native culture on the globe. Accordingly, the GUS will define a "quality education" as one that promotes an integration of the social, economic, political, and spiritual insights of East and West, North and South, masculine and feminine - encompassing the wisdom of the past, the richness of cultural diversity and the transformative potentialities of the present and future.

The GUS partnership of universities, businesses, governmental, nongovernmental, and community organizations will be guided by, and remain fully responsive to, the perceived needs and stated aspirations of students, workers and individual citizens around the globe. The GUS will work diligently to help make it possible for researchers in significant fields of study to collaborate across national boundaries, engaging in joint research projects facilitated by computer, telecommunication and information technologies. A rich new interplay of disciplines and schools of thought is possible through such electronic cooperation and interchange. By bringing many minds together through computer networking and conferencing, our "collective intelligence" can be brought to bear in exploring fresh approaches to global issues.

But the global problems to be addressed include widespread human suffering: physical, emotional and spiritual 
anguish, and distress. This suggests that exchanges between and among researchers, faculty and students must be more than intellectual. An affective component seems required. Through intercultural transactions in the arts and humanities, through more intimate interpersonal exchanges, the heart must be engaged as well as the mind. If compassion, trust and empathy are to be fostered, if a sense of global solidarity is to be attained, we must be willing to share our feelings as well as our ideas.

The GUS endorses the precept of unrestricted access to all information and educational resources at its disposal. The GUS is committed to the goal of counteracting the depersonalizing effects of mass technology. But rather than limiting itself to the aim of meeting the purely personal needs of its participants, the GUS hopes that its educational programmes will encourage a sharing of minds and hearts across personal, disciplinary, scientific and cultural barriers. Both in the formal courses of instruction and in the post-graduate networks of colleagues that emerge from a GUS education, we hope to promote awareness of cultural diversity without encouraging either cultural fragmentation or cultural homogenization, as performing a dynamic synthesis of unity and diversity, a transcultural unity-in-difference.

In order to achieve these goals in educational institutions and society at large, general and inclusive media education programmes are needed at all levels.

\section{Example of an action plan for developing media education in Finland}

Due to the importance of media and digital literacy and competencies, in 2007 the Government of Finland published a Proposal for an action programme for developing media skills and knowledge as part of the promotion of civil and knowledge society. The reason for setting up this committee was the topicality and importance of media education as part of citizenship skills and the problems encountered in its realisation.

The basic and upper secondary core curricula stress communication and media skills (media literacy). In the core curricula for initial vocational education and training, media education is included in the objectives for core knowledge common to all fields. The implementation of media education requires support and new solutions, the concretisation of media education in local curricula and its integration into school practices and culture and into teacher education.

According to the committee, media skills and literacy mean an individual's understanding of the media and their operation in society and meaning in one's own life, the mastery of key skills and the application of information to practice. The committee prepared its action programme on the basis of the report on national development needs in media education (2005) included in the Government's Citizen Participation Policy Programme. In media education, students are unequally placed: schools and teachers are not similarly equipped to take care of media education. Materials and equipment are inadequate for the needs of media education, and copyright questions are a daily concern for teachers. Teaching media education requires technical knowledge and equipment. It has also been suggested that media education and ICT be combined. The blurring of public and private communication with the emergence of the social media has been a particular challenge for educators.

In recent years, learning environments have come to the fore in a new way in discussions. The media and ICT are a crucial part of the future learning environment. People encounter them at work, in education, in hobbies and in free time and they increasingly interlace. Broadband connections and easy-to-use web publication software and platforms enable users to participate on a broad scale in the production and distribution of knowledge, materials, works, etc. Formal, non-formal and informal learning interlink and support each other, forming a lifelong continuum. The media have a strong impact on children's and young people's growth and socialisation. The wide exposure on the internet has caused a new kind of concern for parents, especially with regard to data security, as an increasing number of young people put their products on the web.

Many different stakeholders have carried out media education projects. Most of these have either ended or are about to end. The committee proposes a media literacy programme to be devised and implemented through extensive cross-sectoral cooperation. The aim would be to improve prerequisites for media education in basic education, at the secondary level and in teacher education with a view to making media education an established part of day-to-day school activities.

The proposed programme would contain five actions: I) Innovative methods of work, 2) Development of local learning centres and local cooperation, 3) Networking and information sharing, 4 ) Technical equipment and access to materials, and 5) Cooperation in development: 
I. The committee regards media skills as central skills in life management and active citizenship and also as tools in the changing work life and free time. Therefore the committee proposes an extensive national and long-term media literacy programme to be started. The programme should be stated in the next Development Plan for Education and University Research.

The aim of the programme would be to improve the prerequisites for media education in basic education, at the secondary level and in teacher education with a view to making media education an established part of day-to-day school activities.

Implementation: The media literacy programme will start during the years 2008-20I I.

Functionaries: The Ministry of Education together with the Finnish National Board of Education, universities, polytechnics, education providers, municipalities, educational institutions and functionaries in the third sector.

\section{I.I Innovative methods of work}

Measures: The field of media education has inspired activity and several projects by different functionaries in the field of media education. The innovative methods of work regarding media education shall be utilized and spread. With the help of coordination, the resources of the functionaries would be directed towards a common objective. If necessary, national cooperation projects shall be started and the projects that are found to be successful shall be supported in order to keep them in progress. Core contents of media education in basic education and at the secondary level shall be developed. It is essential that a responsible and safe media environment is created to be able to utilize media literacy in the implementation of the citizens' freedom of speech.

Inspiring and encouraging media education is the premise for building a safe media environment. Schools, teachers and homes need diversified support to be able to create a safe media environment. The joint responsibility requires the development of functional operations models in cooperation with the media and the functionaries in the third sector, too.

Proficiency level descriptions shall be prepared for media education. They shall take into consideration the changes in the media field and in the uses of the media. A specialist group shall draw up concrete objectives from the general objectives and core contents of the cross-cur- ricular theme "media" and draw up a more detailed scale of proficiency level descriptions for basic education.

\section{I.2 Development of local learning centres and local cooperation}

Measures: Educational institutions will be developed into learning centres which promote the development of media literacy, lifelong learning and active citizenship. The forms of cooperation between local operators are essential, but new ways of thinking and cross-administrative decisions are needed, too. Cooperation between home, school and the library is essential in the core contents of media and study skills and thus the activities of school libraries should be developed in the municipalities in cooperation between different school forms and administrations to meet the requirements of data management and media education.

\section{I.3 Networking and information sharing}

Measures: A portal to link the functionaries of media education and support teachers shall be developed. The field of media education needs a unifying internet-portal to support the work of the teachers. The portal should contain relevant curriculum support, information on the available materials, school projects, cooperation projects between the functionaries in media education and schools, contact information etc. Together with the functionaries in the media education field, the Finnish National Board of Education will see to it that the portal will support the needs of the teachers and the implementation of the media theme (key skills in vocational education and training) in basic education, general upper secondary schools and in vocational education and training.

\section{I.4 Technical equipments and access to materials}

Measures: A plan shall be drawn up to support the schools in acquiring up-to-date equipment and materials so that they will be able to advance media education. The following issues shall be taken into consideration when drawing up the plan: the inadequate and inappropriate media education equipment, copyright questions of different sources and materials, the schools' and educational institutions' possibilities of acquiring materials, and the rights of displaying the pupils' own media productions, especially the music in the multimedia and recording productions. It 
is especially urgent to reach an agreement on the digital distribution relations.

\section{I.5 Cooperation in development}

Measures: A common forum for the development of media education shall be established during the programme with the view to plan and coordinate the activities, roles and cooperation of teachers, teacher trainers, researchers, the third sector and other functionaries in basic education, at the secondary level and in the field of media education.

\section{The development of teacher education and the strengthening of media education research}

- The contents of media education shall be increased and diversified in teacher education taking into consideration the changes in the media field and media use.

- Media education shall be established as a theme in the multidisciplined virtual studies in teacher education

- Distance teacher training and distance learning in teacher education will be developed and the synergy benefits with the development of the field school network will be utilized.

- The state-funded resources of the in-service training for teaching personnel will be directed so that at least Iooo participants are able to join the in-service training of media education each year. In-service training for the administrations of educational institutions is essential.

- New and more efficient forms of in-service training shall be developed in order to find concrete ways to support teachers to integrate media education into day-to-day school activities. Forms of in-service education which train the whole school personnel in its own working environment shall be developed.

- Media education research, assessment and the networking of media education researchers shall be promoted and supported.

- The extent to which the media education has been implemented as a cross-curricular theme and in different subjects shall be evaluated. The implementation and efficiency of media literacy programmes shall be followed by research.
Functionaries: The Ministry of Education, together with the Finnish National Board of Education, universities, polytechnics, education providers, municipalities, educational institutions and the functionaries in the third sector.

There is an increasing need for a new renaissance in education where technology, art, science and humanities as well as religion are integrated. We are facing a third major educational invention in technology. The first was the phonetic alphabet, the second printing, and now the third is telematics, which means computers connected to networks. The idea is to remove barriers to access and connectivity, support professional development, accelerate e-Learning innovation and content development, address the ICT skills shortage, promote digital literacy and lifelong learning, and explore sustainable public private partnership.

\section{Sources}

ACADEMY OF Finland; tekes (2006). FinnSight 20 I5: The Outlook for Science, Technology and Society. Helsinki. MINISTRY OF EDUCATION OF FINLAND (2007).

Proposal for an action programme for developing media skills and knowledge as part of the promotion of civil and knowledge society.

RUOHOTIE, PEKKa; MACleAN, RUPERT (eds.) (2006). Communication and learning in the multicultural world. Festschrift for Professor Tapio Varis. Hameenlinna, Finland: University of Tampere, Research Centre for Vocational Education.

unEsCo (2005). Towards Knowledge Societies. Paris: Unesco. ISBN 92-3-104000-6.

varis, taPio (2007). "Finnische Hochschulpolitik". In: "Innovationssysteme im globalen Wettbewerb - europäische Modelle und Reflektionen”. Diskussionspapier der Alexander von Humboldt-Stiftung I0/2007. Bonn: Alexander von Humboldt Foundation. VARIS, TAPIO; UTSUMI, TAKESHI; KLEMM, WILLIAM (eds.) (2003). Global Peace Through The Global University System. Hameenlinna, Finland: University of Tampere. Saarijarven Offset Oy. ISBN 95 I-44-5695-5. 


\section{Recommended citation}

VARIS, TAPIO (2007). "New technologies and innovation in higher education and regional development". In: "Universities and Regional Development: the challenge in the era of the globalisation of higher education" [on-line monograph]. Revista de Universidad y Sociedad del Conocimiento (RUSC). Vol. 4, no. 2. UOC. [Date of consultation: $\mathrm{dd} / \mathrm{mm} / \mathrm{yy}]$.

$<$ http://www.uoc.edu/rusc/4/2/dt/eng/varis.pdf>

ISSN I698-580X

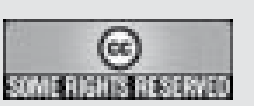

Los textos publicados en esta revista están sujetos - si no se indica lo contrario- a una licencia de Reconocimiento 3.0 España de Creative Commons. Puede copiarlos, distribuirlos, comunicarlos públicamente y hacer obras derivadas siempre que reconozca los créditos de las obras (autoría, nombre de la revista, institución editora) de la manera especificada por los autores o por la revista. La licencia completa se puede consultar en http://creativecommons.org/ licenses/by/3.0/es/deed.es.

\section{About the author}

Tapio Varis

Professor and Chair of Vocational Education, with particular reference to global learning environments, University of Tampere, Finland. UNESCO Chair in Global e-Learning tapio.varis@uta.fi

Professor and Chair of Vocational Education, with particular reference to global learning environments at the University of Tampere, Finland, Research Centre for Vocational Education, and UNESCO Chair in global eLearning with applications to multiple domains. Principal research associate of UNESCO-UNEVOC. Acting President of Global University System (GUS). Former Rector of the University for Peace in Costa Rica. Expert on media and digital literacy to the European Union. Communication and Media Scholar at the University of Helsinki and the University of Art and Design in Helsinki. and the University of Lapland, Finland. Published approximately 200 scientific contributions. 